\title{
Power Consolidation of Jokowi's Administration: The Role of the Social Media and Political Issues in Indonesian Democracy
}

\author{
Ahmad Sahide \\ Universitas Muhammadiyah Yogyakarta, \\ Jl. Brawijaya, Geblagan, Tamantirto, \\ Kec. Kasihan, Bantul, Daerah Istimewa \\ Yogyakarta 55183, Indonesia
}

DOI: https://doi.org/10.36941/ajis-2022-0014

\section{Abstract}

Joko Widodo (Jokowi) is the first Indonesian Democratic President elected by the peripheral people and not the elite. Jokowi is the only Indonesian President that is not the leader of any political party. Therefore, the President was faced with the issues of power consolidation in the initial administrative years. Some professional elites failed the President because they assumed a possible overthrown. During the presidential election in 2019 with Prabowo Subianto, Jokowi took K. H. Ma'ruf Amien as a vice presidential candidate and was attacked by China and the Indonesian Communist Party (ICP/PKI). However, Jokowi was re-elected for the second period (2019-2024) due to his close relationship with Indonesians, which is different from other presidents.

Keywords: Indonesia, Joko Widodo, Prabowo Subianto, power consolidation, Second Contest, political power, social media, and popularity

\section{Introduction}

The General Electoral Commission (GEC/KPU), on July 22, 2014, officially announced Joko Widodo and Jusuf Kalla (Jokowi-JK) as the winner of 2014 to 2019 Presidential and Vice Presidential election held on July 9. The pair defeated Prabowo Subianto and Hatta Rajasa with 70,997,833 votes (53.15\% percent) against $62,576,444(46.85 \%)$ out of a total valid votes of 133,574,277 (www.voaindonesia.com, Pratama, 2015).

The victory led to some doubts and anxieties from several societal elements due to the chairman of the Indonesian Democratic Party of Struggle (PDI P) because the elected pair was raised under the shadow of Megawati Soekarno-Putri. Meanwhile, Megawati was the 5th President of the Republic of Indonesia and the daughter of Soekarno, and it was one of the reasons Jokowi was perceived as a puppet. Although Jokowi is more popular, Megawati is more powerful.

On April 17, 2019, a re-contest of the presidential election was held between Jokowi accompanied by K.H. Ma'ruf Amien, a prominent figure from Nahdatul Ulama and Prabowo Subianto with its vice presidential candidate Sandiaga Salahuddin Uno. Sandiaga is a successful young businessman and the Vice Governor of DKI Jakarta from Anies Baswedan. This was Jokowi's second victory with 55,50 percent, against 44,50 percent obtained by Prabowo. Jokowi and Amien, as well as 
Prabowo and Sandi, realized 85.607.360, and 68.650.239 votes, respectively (Kompas, 22/05/2019).

\section{Jokowi; From Solo to Jakarta, the Special Capital Region}

Jokowi was a new figure that contested for the President of Indonesia in 2014 and was widely known as the Solo Mayor for 2 periods. Jokowi's success in leading this city led to their popularity. In 2012, Jokowi contested for the Governor of Jakarta, and was paired with Basuki Tjahaya Purnama (Ahok). Finally, they won with 53.82 percent, whereas Fauzi Bowo-Nahrowi Ramli, the incumbent candidate, obtained 46.18 percent of the valid vote (Yew-Foong \& Bakti, 2015). The Jokowi-Basuki pair was obtained from a primary coalition because they are both PDI P and Gerindra cadres. In comparison, Golkar Party nominated Fauzi Bowo-Nahrowi Ramli, the National Mandate Party (PAN), the People's Conscience Party (Hanura), National Awakening Party (PKB), Crescent Star Party (PBB), and Awakening Party of Nahdatul Ulama.

The people were mainly concerned with the Gubernatorial election held in DKI Jakarta, especially Sabang and Merauke, including the international spotlight. Jakarta residents hoped that Jokowi's reign as Mayor of Solo became a substantial capital for fixing this city, especially in overcoming traffic jams and floods. After being inaugurated as Governor of Jakarta, Jokowi often demonstrated Blusukan (to visit down) to understand the root of the problem. In addition, the citizens were impressed by their leadership.

Jokowi's support from modern technology became increasingly popular in the national arena because the informational media was no longer under the strong control of the state, such as in the New Order era (Kitley, 1994). This figure was not only known by the citizens of DKI rather by Indonesians both home and abroad. After leading Jakarta for a year, the name Jokowi also emerged as one of the famous figures for the presidential candidate in 2014. However, several elements doubted his capacity because Indonesia is different from Solo and DKI Jakarta. It is an undeniable fact that Jokowi is popular and the pair were considered to be incapable. People thought that Jokowi was inexperienced and lacked a solid political network.

Jokowi's position as a PDI-P cadre made these elements believe that Jokowi was a shadow of Megawati. However, after becoming the Governor of DKI Jakarta, Jokowi's popularity increased compared to other figures, including Megawati. Irrespective that Megawati was much stronger, Jokowi was much more popular and had high electability. Megawati was still interested in being the President, and assuming they kept pushing themselves back in 2014, Megawati was likely to be defeated for the third time. This was one of the dilemmas Jokowi faced in 2014 because people often presumed Jokowi's electability as the presidential candidate on many occasions. When asked about the electability, Jokowi stated that it depended on Mrs Mega.

\section{Megawati's Pressure from Social Media}

Social media is an integral part of democracy and one of its pillars. According to Budiyono (2016), it plays a vital role in political communication. The use of social media for a political campaign is not a new phenomenon in digital democracy (Leiliyanti \& Friends, 2020). Meanwhile, its impact was felt by Indonesians after the New Order era. The current social media helped the people discover the ideal figure to be nominated as a leader (President and vice president). Nowadays, the elite and the public interact through existing media channels (Rizkimawati \& Kusumawardhana, 2021). Jokowi is one public figure that benefitted immensely from modern social media.

Lower-class groups and civil society organizations boosted Joko Widodo's populism alongside social movements that utilized mainstream outlets and internet-based media to foster democratic agendas in the country (Mietzner, 2015; Aspinall, 2013). Social media pressured Megawati to nominate Jokowi as the presidential candidate from PDI P in 2014, based on the popularity. Even though the public saw that Megawati was reluctant to provide access for Jokowi, Megawati was unable to face the pressure from society regarding Jokowi's electability. 
Finally, Megawati responded through a handwritten letter dated March 14, 2014, gave the phenomenal cadre a mandate to become the presidential candidate from 2014 to 2019. This admittedly reflected the greatness of Megawati, as a senior politician whose speeches were undeniable in PDI-P, coupled with their ruling experiences, Megawati still had the mind to return to the formerly occupied position. However, the public expectations of Jokowi were high, and this proved victory supposing given the mandate, Megawati was finally willing to give way for Jokowi. As a senior and experienced politician, Megawati realized that the momentum of political victory sometimes did not come twice, therefore, it does not need to be wasted. After a tight and heated battle that split the people, Jokowi paired up with Jusuf Kalla (JK), and both emerged as the winner of the presidential and vice-presidential election in 2014.

\section{Mapping of Coalition 2014}

The 2014 presidential and vice-presidential election only lasted 1 round as there were only 2 candidate pairs contesting, namely Joko Widodo (Jokowi) and Jusuf Kalla (JK) against Prabowo Subianto and Hatta Rajasa. Jokowi and JK were nominated by PDI-P and the coalition of PKB, Hanura, Nasdem and PKPI. Therefore, Prabowo Subianto and Hatta Rajasa were promoted by Gerindra, PAN, Golkar, Prosperous Justice Party (PKS), United Development Party (PPP), and PBB. PKPI and PBB were the 2 parties that lacked delegates in Senayan (Sahide, 2020). The democrats, the winner of the 2009 election, declared to be neutral. Some of its cadres, however, supported Jokowi and JK, while some supported Prabowo and Hatta. Non-party figures also took a different stance. For instance, Mahfud $\mathrm{MD}$, former Chief Justice of the Constitutional Court (MK), became the Prabowo and Hatta success team's head, while Anies Baswedan was the spokesperson for that of the Jokowi and JK. Therefore, this study question is how to read the coalition map?

In accordance with analyzing the coalition map of political parties in Indonesia, Kuskridho Ambardi stated that competition based on ideology only occurs ahead of elections, especially that of legislators, and when it ended, the rivalry also comes to a halt. Politics with a cartelized system follow this, and according to Lombardi, it began to take shape in 1999 and re-attended the recycling of democracy in 2004, including the 2009 general election (Ambardi, 2009). Reading the coalition map in the July 2014 presidential election, Kuskridho Ambardi's thesis is extremely accurate in terms of creating a political cartel. The built alliance is not based on ideological similarities rather on the division of seat allocations and power. However, the establishment of political parties is acknowledged by both partners not because of ideological factors and similar platforms, rather, it is based on the cartels. The Jokowi and JK party coalition, for instance, consisted of the nationalist PDI$\mathrm{P}$, which merged the ideologies of Sukarnoism, along with the strong PKB and the Nahdatul Ulama (NU) nuances as well as Hanura and Nasdem.

It is noted that PKB, during Susilo Bambang Yudhoyono, was one party that supported the government, while PDI-P and Hanura were outside the government. Meanwhile, Prabowo and Hatta's coalition party consisted of Gerindra, which seemed like a socialist and anti-foreign, in this case, the United States, and PAN, which was claimed by the Muhammadiyah and had been enjoying the government's cooperation under the SBY's administration. Some PPPs call themselves Islamic parties. Meanwhile Golkar joined at the last moment after failing to build a coalition with Democrats.

Relating to a brief analysis of the 2 camps, it was discovered that the coalition they built was not based on ideology rather the cartel's political system. Ahead of the Probowo and Hatta pair declaration, some coalition parties threatened to withdraw their support because Prabowo did not choose their cadre as a running mate during the July 9 presidential election. It was further reported that PKS presented 3 of its cadres as vice-presidential candidates. However, the threatening party seemed to have no choice but join the Jokowi, and the JK stronghold undermined political dignity. Conversely, it was also impossible for their candidates to be selected. They were forced to and even perhaps halfheartedly supported Prabowo and Subianto pair. Meanwhile, there was no political turmoil among Jokowi and JK's supporters' coalition as experienced by that of the Prabowo and 


\section{Hatta's.}

The second attribute of the coalition built was a personal factor related to the party flag. SBY personally backed Jokowi's complex statement not to support any presidential candidate that intends to nationalize state assets from the beginning of the political development. This statement addressed Prabowo and his decision to engage in such an act (Mietzner, 2014). However, Megawati Soekarno Putri failed to respond because it seemed they still held a political grudge against SBY's choice of candidates from PDI-P. SBY further stated that Democrats were neutral, and its cadres were free to vote. This was because of the already delivered loud speech to reject Prabowo, in addition, Megawati also failed to accept the Democrats to be a part of the coalition. Least of all, Prabowo appointed Hatta Rajasa, whose daughter married SBY's son. Therefore, the neutral Democratic political attitude was strongly influenced by their lousy relationship with Megawati and Hatta Rajasa.

Similarly, Golkar left Gerindra and hoped to join the PDI-P wagons. However, the appointment of Jusuf Kalla's name as a vice-presidential candidate for Jokowi caused ARB to swerve and brought Golkar back to the wagon established by Gerindra. It was suspected that Golkar's attitude towards Prabowo and Hatta was due to personal rivalry between ARB and JK. Akbar Tanjung initially appointed ARB as a presidential candidate, was also involved with Prabowo. This was due to the fact that Akbar Tanjung still holds a personal grudge against JK that defeated him during the Golkar congress in 2004.

\section{Reading Jokowi's Victory}

All Indonesians enlivened the 5-year democratic party on July 9, 2014, after Joko Widodo and Jusuf Kalla (Jokowi-JK) emerged the winners (Panuju, 2019). Some survey agencies had already predicted their victory before the election. The majority put their pair ahead of Prabowo and Hatta, although they were seized with the fear of losing. Instead, the pair were always under Jokowi and JK, despite hoping to emerge as the winners. Since they were officially declared members of the Indonesian Democratic Party of Struggle (PDI P), Jokowi has been facing various irrational attacks. One of the most noteworthy was Jokowi's character assassination through the "Obor Rakyat" media, which allegedly involved the palace. Meanwhile, their electability was increasingly overtaken by Prabowo and Hatta's. Without denying that their running mates Prabowo and Hatta also gained negative attacks, it was not as massive as Jokowi and JK. Before the July 9, 2014 election, this led to reason their superiority, which was overwhelmed by anxiety while Prabowo and Hatta, though left behind, were optimistic about winning. Not to mention the power of funds and political parties with prominent figures that could strategize.

Therefore, considering these competitive and powerful party machines, the actual contestation was over before July 9 because Prabowo's team embraced all experienced and mature political forces in their ranks compared to Jokowi and JK. Prabowo and Hatta's campaign management, recognized by Edward A Spinall (2013), was much more organized than the other teams. The strategy seemed to be quite effective because the Prabowo and Hatta pair was narrowly defeated by Jokowi and JK's, in which previous survey results seemed unchallenged.

Therefore, supposing this study is analyzed from the aspect of the characters joining the ranks, the supporting political parties, the power of the media, and funds, including the strategy adopted to influence public opinion, the Jokowi and JK team had lost. One factor that led to their emergence as the winning team was the volunteers' strength by non-governmental organizations, and the mobilization of social activists throughout the country to thwart Prabowo and Merdeka Palace past activities. However, they were unwilling to elect them as President and Vice President. The movement to thwart Prabowo was due to Jokowi and JK's influence in the face of political strikes formulated by parties and figures loaded with experiences and supported by unlimited funds. 


\section{Jokowi Fight Against the Myth}

In accordance with the 8 elements in theory proposed by Robert A. Dahl, democracy creates a space for people from all walks of life to participate in political contestation, whether to vote or be voted for, building control over accountable governments (Dahl, 1971). The Election of Joko Widodo (Jokowi) and Jusuf Kalla (JK) as the President and Vice President of Indonesia is an indicator that democracy is getting healthier. There are at least 2 factors that prove the aforementioned statement. Firstly, Jokowi is the first elected President that is not a party controller (Chairman). Jokowi and JK were the best cadres of PDI P under Megawati Soekarno Putri that were nominated for President on July 9, and they finally won. Megawati's willingness to allow non-elite cadres proved that Putri was able to listen to the people's voices.

Secondly, Jokowi and JK's Election to lead this nation and state over the next 5 years is an essential history in Indonesian political dynamics since achieving independence in 1945. Jokowi is the first president from the periphery to lead the country. Fachri Ali described it as "Post-elite Leadership." Democracy paves the way for anyone to be a leader, as well as also aids to select the best, that are unable to be hijacked by political party. In addition, it does not only create chances for the elite.

Therefore, Jokowi and JK's victory was that of the people and the progress of democracy, albeit with some shortcomings and manipulations. This was proven by the citizens' massive participation and the volunteers, that were not mobilized during the presidential and vice-presidential elections last July, which delivered their candidates in front of the Palace gate. They also actively controlled forming the Jokowi and JK cabinet, which is the second condition of substantial democracy. The third is the firm's unflinching support of the leader to maintain accountability.

\section{Democracy Against the Elite}

The Election of Jokowi represents the 3 elements, and, presently, the Indonesian democracy has adopted the US trajectory that fights the myth related to the elite's domination. However, before the Election of Barack Obama in 2008, America has always been driven by certain elites that had long controlled political power because they believed that the President of the USA needed to be White. Obama was the one that arose against the dominance of the elite and political myths in that secular state as the first Black President.

The political history of Indonesia has certain similarities with America, although it has been hijacked by the elites that believe in the Javanese myth of Notonagoro. During the campaign period, Jusuf Kalla once stated that the elites supported the Prabowo and Hatta team. In contrast, the Jokowi and JK campaign was supported by volunteers. Before July 9, many predicted the win of Prabowo Subianto due to their belief in this myth. Jokowi was against Prabowo and also the myths. July 9 became a historical record in the Indonesian democracy because it has succeeded against the elite's domination and even the myth.

The reality that Jokowi and JK won got backlash from the elites that seemed unable to accept the results of the democratic process to be marginalized. Many observers believed that the political parties' efforts supported Prabowo and Hatta to change the indigenous electoral law, from direct elections by the people to the Local House of Representatives. It was the final attempt to attack and disrupt the Jokowi and JK governments.

Moreover, the elite seemed to be haunted by the fear of being marginalized (away from the centres of power) because of their inability to compete in a democratic system to win the people's hearts. The powerful Golkar in the New Order era failed to gain political contestation. In 2004, Wiranto was appointed as a presidential candidate which Golkar was defeated. In 2009, Golkar had appointed Jusuf Kalla as a presidential candidate accompanied by Wiranto and was again faced with political failure. The 2014 presidential and vice-presidential election was even more embarrassing for Golkar because the role of cheerleader needed to be played, even begging from the political 
contestation whose card was held by PDI P and Gerindra even though Golkar emerged the second winner during the legislative elections.

At this point, the difference between American and Indonesian democracy is quite visible. In the United States, Obama managed to fight the elite myth, as well as Jokowi. The only difference was that Obama did not get opposed after entering the White House, while Jokowi faced several challenges, even before entering the palace. This means that the Indonesian democracy still lags behind that of Americans. The people accepted the outcome of the democratic process, unlike the elites. They need to learn to be democratic during such victory and when defeated. It cannot be denied the democratisation in Indonesia is certainly still far from the ideal format structurally and culturally (Azhar et al., 2020).

\section{Megawati and Jokowi-Jk; An Ideality}

Political parties are indeed the primary pillar of the democratic system, and according to Indonesian history, every President in this republic is always in control, and this serves as the basis of support. Soekarno had established the Indonesian Nationalist Party (PNI). Soeharto also made the basis of political support, namely the Golongan Karya (Golkar). After Soeharto's resignation, BJ Habibie became the transit President of the country. Habibie also made Golkar the basis of political support, although it was not taken seriously and was eliminated from the competition to RI 1 in 1999.

In the reformation era, KH. Abdurrahman Wahid (Gus Dur) and Megawati Soekarno Putri were elected as the President and Vice President of Indonesia. Gus Dur was the founder and leader of PKB, while Megawati is the PDI P chairwoman, till date. During the democratic recycling in 2004, Susilo Bambang Yudhoyono (SBY), a central figure of the Democratic Party, paired with Jusuf Kalla (JK), and emerged as the winner.

A glimpse of the post-independence journey proves that all the presidents are top leaders of political parties. The results of the July 9 presidential election presented a different nuance in the Indonesian culture. The elected President and Vice Presidential Candidates were not the top leaders of any political parties.

These facts raised doubt that Jokowi was going to be perceived as Megawati's puppet, given the destiny to be the President. Besides God's appointment, there was Megawati's final blessing. However, this doubt needed to be cleared by both during the first period of Jokowi's administration. Megawati has to learn from the US democracy, where the President does not need to be the chairman of any political party. Barrack Obama, the former President of America, was not the chairman of the Democratic Party. Obama's relationship with the party supporters, Democrats, was ideological.

Megawati needs to learn from that case and develop an ideological relationship with PDI P, Jokowi, and JK. As Chairman of the PDI P, Megawati is responsible for maintaining the party's ideology, while Jokowi and JK ensure it is functional. In that context, there need be no doubt that the elected President was going to be a puppet. Moreover, Indonesia embraces a democratic presidential system, therefore, it is the sole responsibility of citizens to appoint or reject rulers. Political parties are only responsible for carrying out their best cadres even though there is often democratic piracy at this stage.

Indonesia held its general election in 2019, and Jokowi was elected as the President for the second time. Megawati had been able to clear the people's doubt. Jokowi is always remembered as an actual figure that led to the establishment of a new trend and an increasingly healthy Indonesian democracy.

\section{Power without 'Power'}

Yasraf Amir Piliang published an article in Kompas daily, on the September 7, 2015, edition, entitled was Power without Power (Piliang, 2015). Piliang asserted that it existed legally, although it was absent and non-functional without "power." It failed to work because their promises and plans were not 
realized. The government wheel's command line was absent because it had no disciplinary effect on the lower apparatus.

From the article, Yasraf Amir Piliang highlighted the leadership of Joko Widodo (Jokowi), that was widely rumored to be a puppet. In other words, Jokowi was regarded as a 'Political Party Functionary.' Megawati Soekarno-Putri conveyed this information during the Fourth Congress of PDI P's closing ceremony on Saturday, April 11, 2015. Megawati reminded the cadres of their duties as party officials and obliged them to carry out these instructions diligently (Kompas, April 12, 2015). There were also speculations that Jokowi was going to become the 'victim' game of experienced politicians. It was true that Jokowi is the President, however the real power is bestowed on the ruling political party and top politicians that have almost 2 decades of experience 'playing' in the Palace circle. In addition, Piliang referred to them as the 'invisible power.'

Yari Nurcahyo, Executive Director of PARA Syndicate, published an article in the same newspaper on December 11, 2015, entitled President without the Crown. This was related to President Jokowi's consolidated power. During this publication, Jokowi's cabinet was reshuffled a couple of months back. Even Piliang's article was a response to the first one that still led to the election of Jokowi, a ruler without power and a Crown.

Therefore, in the early days of the Jokowi and JK's reign, the public presumed that they might be overthrown in the middle of their administration, especially after the presidential and vicepresidential elections. Prabowo's defeated stronghold led to the establishment of the Red and White Coalition (KMP), which successfully controlled the House of Representatives' top leadership. PDI P, the winning party, was not appointed any political position in the legislative. Jokowi was then compelled to make a political compromise in dealing with the invisible power. This fear haunted Jokowi's administration during the first year.

\subsection{Reshuffle and seizing the thrown}

On July 27, President Jokowi reshuffled the cabinet for the second time. Some ministers including Anies Baswedan, and others were substituted. Golkar Party and PAN were each 'rewarded' with a seat in the Working Cabinet. This manifested Jokowi's resumption power and prerogative right, as requested by Yari Nurcahyo (Sahide, 2020). Following the cabinet's reshufflement process, it is evident that Jokowi had obtained the real power and Crown.

The cabinet reshufflement on July 27 proved that Jokowi was the one that set the 'rhythmic game.' Megawati and PDI P no longer appeared as the dominant actors in the palace. This is seen a few months before the cabinet was reshuffled, PDI P elites discoursed that the party needed to get at least 4 seats. Besides, the public also knew that some members were 'disliked' by Megawati, although, Jokowi still retained them. Vice President JK, an experienced top politician, was also not prominent in reshuffling the cabinet. Even one of the members suspected of being JK's favourite was also discharged. Luhut Binsar Panjaitan (LBP), one of the influential people in Jokowi's government, was also reshuffled for almost 2 years. Wiranto replaced Panjaitan as the Coordinating Minister for Political, Legal, and Security Affairs. Golkar was appointed one seat in the Jokowi and JK cabinet even though it was maneuvered by declaring their support for Jokowi in 2019 on the same day the cabinet was reshuffled.

The reshufflement in July 2015 was an event for Jokowi's administration to prove their power (strength). Jokowi was fair and did not exhibit 'dominant power' to certain political parties. Therefore, Jokowi was able to dictate the rhythm of the Indonesian political stage because the administration had the power and the Crown. One critical factor of consolidating their power was the support of modern technology, social media. Fortunately, Indonesia is one of the 'online countries' globally (Lim, 2013). Until the end of the first administration in 2019, Jokowi successfully consolidated its power against opponents championed by nationalist, populist and religious causes (Wicaksana, 2019). 


\section{Second Contest of Jokowi Versus Prabowo in 2019}

As a president, Jokowi was credited with some of the greatest breakthroughs in establishing a political culture in Indonesia. This administration adopted different styles, as well as introduced the term 'blusukan'. Jokowi also intends to alter the Indonesian's bureaucratic culture by changing the popular mindset with the term "mental revolution" irrespective of its unsuccessful.

Furthermore, Jokowi built a big project, namely the 'sea toll' (Tol Laut), which led to the establishment of inter-island connectivity on the outskirts. This administration built 27 seaports, 4 ferry ports, 7 new airports and expanded 12 of them in the eastern part of the country (Kompas, 6/04/2016). During Jokowi's 5 years of administration, attention was paid to the non-Java provinces, mainly Papua, because they lacked behind.

Therefore, before the second Cabinet reshuffle in 2016, Golkar first declared its support for the Jokowi administration in 2019. Some political parties also expressed their support. For example, the United Development Party (PPP) declared its support on July 21, 2017 (Kompas.com). Other parties include Hanura Party, the Indonesian Justice and Unity Party (PKPI), and the Indonesian Solidarity Party (www.tribunnews.com). Megawati Soekarno-Putri officially nominated Jokowi as the presidential candidate on February 24 2018, in Bali (Kompas, 24/o2/2018).

Towards the end of the President and Vice President Election's registration deadline, August 1o, 2018 , some potential figures appeared to accompany the 2 candidates. In the case of Jokowi, some figures were reportedly mentioned on social media to be the running-mate in the 2019 general election. Those were Muhaimin Iskandar, Airlangga Hartarto, Moeldoko, Moch. Mahfud, MD, KH. Ma'ruf Amin, Din Syamsuddin. Whereas, for Prabowo, Agus Harimurti Yudoyono (AHY), Ustadz Abduh Somad (UAS), Salim As Segaf, dan Zulkifli Hasan were reportedly mentioned on social media.

Finally, Jokowi's political party coalition appointed KH. Ma'ruf Amien was the vice-presidential candidate, while Probowo chose Sandiaga Salahuddin Uno, the vice governor of DKI Jakarta. Burhanuddin Muhtadi, Director of Indonesian Politic Indicator, published an article on Kompas stating that Jokowi chose Ma'ruf Amien due to the elite's political compromise. Ma'ruf Amin is the leader of Nahdatul Ulama (NU), the Islamic mass organization constituting relatively 60 million Indonesians. Besides, Ma'ruf Amien is the Cheaf of Majelis Ulama Ulama Council (MUI). By working simultaneously with Ma'ruf Amin, Jokowi thought that most NU followers (Nahdiyin) were bound to vote for their team. Another consideration was that Ma'ruf Amien usually counters issues raised by their rivals (Prabowo team), which indicates that Amien was anti-Islam and Jokowi was part of the Communist in Indonesia. China is prominent in coloring Jokowi's campaign during the general election in 2019.

Practically, no other figure was able to contest Jokowi's popularity apart from Prabowo Subianto. Therefore, the 2019 general Election was the second contest between these 2. Based on some surveys carried out before the Election, Jokowi had the enormous possibility to win. The study carried out by Lingkaran Survei Indonesia, or the Indonesian Survey Circle (LSI/ISC) on April 3, 2019, Jokowi had high electability, relatively 56,8 percent compared to the 43,2 percent of Prabowo Subianto. It was slightly different from the analysis carried out by Vox Populi, where Jokowi-Amien had 54,1 percent of electability and Prabowo-Sandi had 33,6 percent (Kompas, 3/04/2019).

The presidential and vice-presidential elections held on April 17 were not different from the initial ones. The Real Count result from the General Electoral Commission (Komisi Pemilihan Umum) was that Jokowi-Ma'ruf Amien obtained 85.607.362 votes, approximately 55,50 percent. Conversely, Prabowo-Sandi obtained 68.650.239 votes which are equivalent to 44,50 percent (Kompas, 21/05/2019). However, Prabowo-Sandi's team did not receive the results and accused Jokowi and Amien of systematic and massive deceit. Even Prabowo-Sandi mobilized the voters for a massive demonstration on May 22 to 23, 2019 in front of the General Electoral Commission office, and the term was "popular power". It was coming from a prominent former politician, Amien Rais.

Some Indonesian scholars were worried about that because it had a significant impact on the country and led to a certain chaos. Even, Prabowo and Sandi declared their victory before the General 
Electoral Commission released the results officially. In this case, they were perceived as unconstitutional figures. They, mainly Prabowo, preferred to emerge as the President of Indonesia by force. After the results were realized, Prabowo and Sandi decided to sue the case in the Constitutional Court. Prabowo and Sandi's lawyers demanded that Jokowi and Amien be disqualified for the systematic and massive deceit. However, the Constitutional Court refused because they were unable to prove their accusations in front of the judges. Therefore, Jokowi won the election for the second time. The President and Vice President of Indonesia for the 2019 to 2024 tenure is Joko Widodo (Jokowi) and K.H. Ma'ruf Amien.

\section{Conclusion}

There are 3 critical stages of Jokowi's consolidated power. In the first administrative year from 2014 to 2015, Jokowi had high legitimacy from the people in general and was weak in part of the elites, despite the fact that they did not have solid political networking. Jokowi was not completely perceived as the President and had problems with Megawati and PDI P, despite being nominated by the main political party. In the beginning, Megawati appeared to put Jokowi as a subordinate and established the term "Political Party Functionary" or "Petugas Partai" for all the PDI P cadres given a chance in the legislative or executive, including President Jokowi.

The second stage is the year of power consolidation, from 2015 to 2016. During the first year of their administration, Jokowi, helped by Vice President Jusuf Kalla, tried to study the political party map from the palace, from the centre of authority. Afterward, this was followed by power consolidation. This made the political party or its coalition divisive and weak, thereby disturbing their administration. Golkar, PPP, and Jokowi also took PAN to be part of the government coalition. Some left Gerindra as the Red and White Coalition or Koalisi Merah Putih (RWC or KMP).

The final stage was the year of being completely in charge, from 2016 to 2017. Jokowi was able to reshuffle the cabinet and make certain political decisions in 2016. Jokowi succeeded in consolidating and sharing the power, as well as being in control. Jokowi was popular and had high electability in facing the 2019 election during the second contest with Prabowo. For the presidential and vicepresidential election in 2019, Jokowi appointed K.H. Ma'ruf Amien, whereas Prabowo chose Sandiaga Salahuddin Uno. However, it was predicted even before the election that Jokowi and Amien would emerge winners.

In this contest, Jokowi was not powerless anymore. They had control of the power, therefore Prabowo and Sandi accused their administration of exploiting the state apparatus, which they were unable to prove.

\section{References}

Ambardi, K. (2009). Uncovering Cartel Politic (Mengungkap Politik Kartel). Jakarta: Kepustakaan Populer Gramedia.

Aspinall, E. (2013). Popular Agency and Interests in Indonesia's Democratic Transition and Consolidation. Indonesia, 96(1), 101-121.

Azhar, M., Sahide, A., Hidayati, M. \& Hasse, J. (2020). A New Perspective on Relations between Islam and Democracy in Indonesia. International Journal of Innovation, Creativity and Change, Volume 13, Issue 5, 2020.

Budiyono. (2016). Social Media and Political Communication: Social Media as Political Communication in facing Local Election of DKI Jakarta 2017 (Media Sosial dan Komunikasi Politik: Media Sosial sebagai Komunikasi Politik Menjelang Pilkada DKI Jakarta 2017). Jurnal Komunikasi, Volume 11, Number 1, October 2016.

Dahl, R. (1971). Polyarchy: Participation and Opposition. New Haven, Conn: Yale University Press.

Indo Baromoter, (2017). Who is the Potential Challenger of Jokowi 2019? (Siapa Penantang Potensial Jokowi 2019?) Survey done on 15th-23th November 2017.

Kitley, P. (1994). Fine Tuning Control: Commercial Television in Indonesia. Continuum: The Australian Journal of Media and Culture 8: 103-23. 
Kompas (2018). Jokowi and Sudden Strategy of PDI P (Jokowi dan Strategi Dadakan PDI P). Saturday, edition of 24th February 2018.

Kompas, 22 May Edition of 2019. Jokowi: Let's Unite (Jokowi: Mari Kita Bersatu). P. 1.

Kompas, 3 April Edition of 2019. Updtae Electability of Jokowi-Ma'ruf and Prabowo-Sandi from 7 Survey Institution (Elektabilitas Terkini Jokowi-Ma'ruf dan Prabowo-Sandi dari 7 Lembaga).

Kompas.com. (2017). PPP Declares of Supporting Jokowi in Presidential Election 2019 (PPP Deklarasi Mendukung Jokowi pada Pilpres 2019). Edition of 21th Juli 2017.

Leiliyanti, E., Irawaty, \& Diyantari. (2020). Religious and political public sentiment towards political campaign in social media: Indonesia and Malaysia cases. Humanities \& Social Sciences Reviews, Vol 8, No 1, 2020, pp 255263.

Lim, M. (2013). Many Clicks but Little Sticks: Social Media Activism in Indonesia. Journal of Contemporary Asia. Vol. 43, No. 4, 636-657.

Mietzner, M. (2014). How Jokowi Won and Democracy Survived. Journal of Democracy, October 2014, Volume 25, Number 4 .

Mietzner, M. (2015). Reinventing Asian Populism: Jokowi's Rise, Democracy, and Political Contestation in Indonesia. Hawai'i: The East-West Center.

Panuju, R. (2019). The Comparison of Jokowi and Prabowo Subianto Exposed on YouTube. Jurnal Ilmu Sosial dan Ilmu Politik, Vol. 22, Issue 3, March 2019.

Piliang, Y. A. (2015). Power without Power (Kekuasaan Tanpa Kuasa). Kompas, edition of 7 th September 2015.

Pratama, E. G. (2015). Analysis of Jokowi-JK Victory in President and Vice President in 2014 in Pelalawan Regency (Analisis Kemenangan Joko Widodo - Jusuf Kalla Pada Pemilihan Presiden Dan Wakil Presiden Tahun 2014 Di Kabupaten Pelalawan). Jom Fisip Vol. 2 No. 2 October 2015

Rizkimawati, D. \& Kusumawardhana, I. (2021). State and Right-Wing Populism: Analysis on the Kemenko Polhukam RI Persuasion Approach in Responding the Wave of "212" Movement. Journal of Islamic World and Politics, Vol. 5, No. 1, June 2021.

Sahide, A. (2020). Kekuasaan dan Mahkota Politik (Power and Political Crown). Yogyakarta: The Phinisi Press https://www.voaindonesia.com/a/kpu-tetapkan-jokowi-jk-pemenang-/1962850.html.

Tribunnews.com. (2017). Declaration of Nominating Jokowi in General Election 2019 Increases, When Will be for PDI P? (Deklarasi Usung Jokowi di Pemilu 2019 Terus Bertambah, PDI Perjuangan Kapan? Edisi, 4 Agustus 2017.

Wicaksana, I G. W. (2019). Economic nationalism for political legitimacy in Indonesia. Journal of International Relations and Development. https://doi.org/10.1057/s41268-019-00182-8

Yew-Foong, H., \& Bakti, I. N. (2015). Watching the Indonesia Election 2014. Singapore: ISEAS Perspective. 